\title{
PROCEEDINGS OF THE SOCIETY OF ANTIQUARIES
}

Thursday, I 5th Fanuary I953. Sir James Mann, President, in the Chair.

The following were elected Fellows of the Society: Dr. C. H. Talbot, Rev. Dom A. Hughes, Mr. H. Duff, Miss J. M. Reynolds, Prof. F. E. Zeuner, Miss M. G. Wilson, Mr. E. H. L. Sexton, Mr. F. B. Gilhespy, Mr. T. A. Lloyd, Mr. N. Walker, Dr. K. P. Oakley, Mr. A. H. Smith.

The Birdlip Mirror was exhibited by the Secretary by permission of the Gloucester Museum.

Mr. R. F. Jessup, F.S.A., exhibited MS. 723, the notes and correspondence of Rev. Bryan Faussett (F.S.A. I $763-76$ ).

Mr. E. M. Jope, F.S.A., exhibited late Saxon pottery from his excavations beneath the Oxford Castle mound.

Dr. W. L. Hildburgh, F.S.A., exhibited a bronze vessel from the Middle East.

Thursday, 22nd Fanuary i 953. Dr. E. G. Millar, Vice-President, in the Chair.

Mr. and Mrs. Leslie Alcock read a paper on Bhambhor: an Arab port in Sind.

Thursday, 29th Fanuary 1953. Sir James Mann, President, in the Chair.

Miss Marion Wilson was admitted a Fellow.

Professor Stuart Piggott, F.S.A., and Mr. R. J. C. Atkinson, F.S.A., read a paper on the Early Iron Age horse-mask from Torrs: a critical analysis.

\section{SIR CHARLES REED PEERS}

Charles Reed Peers, Knight, C.B.E., F.B.A., F.R.I.B.A., Litt.D., D.Lit., D.C.L., M.A., filled in succession the offices of Secretary (I g08-2 I), Director (I92 I-9), and President (1929-34) of this Society.

He was born at Westerham on 22nd September I 868, the son of the Rev. William Henry Peers, and was educated at Charterhouse (of which he was later to be a governor) and at King's College, Cambridge.

In I 893 Peers and our Fellow, the late Sir George Hill, presented themselves together as candidates for a junior post at the British Museum. Hill was the successful one. From this meeting in early manhood the two formed a close and intimate friendship which lasted their joint lives. .Some forty years later Hill rose to be the Director of the Museum at the same time that Peers was a member of the Board of 'Trustees. It was Peers who wrote his friend's obituary notice in these pages.

Later in the same year Peers became a pupil of Sir Thomas Jackson, the architect, in whose office he worked for the next three years. This practical training was of the greatest value to his future work, both in the Inspectorate of Ancient Monuments and in his subsequent supervisory posts.

$\mathrm{He}$ was elected a Fellow of this Society in $190 \mathrm{I}$. Two years later he became architectural editor of the new Victoria County History. His course was now set. In I 910 he was appointed an Inspector of Ancient Monuments under the Office of Works and became Chief Inspector in I9I3. For a quarter of a century he devoted his very individual talents to this great public service. No one else could have brought to the work the same combination of gifts.

His love of gardens rejuvenated the neglected piles of castles and abbeys with mown lawns and bright flowers. No ivy-mantled towers were left for owls to lament in. He founded a school of conservation which was a model to the world and one earnestly hopes will long survive him. He was largely responsible for two Acts of Parliament promoting the care of ancient monuments.

For forty years he was a devoted servant, counsellor, and leader of this Society, for which he had a deep affection. His busy life prevented his writing any large book, but he contributed numerous papers to Archaeologia, the Proceedings, and the Fournal, and elsewhere, and his influence on other workers in his field was great.

On his retirement from the public service a new phase of activity began for him. He wryly said that he was now busier and better off than he had ever been as a Civil Servant. His services as advisor were competed for by those responsible for our most important ancient buildings. He was appointed Seneschal of Canterbury Cathedral, Surveyor of Westminster Abbey, architect-in-charge of Durham Castle, consulting architect of York Minster and Durham Cathedral. He was called in to advise the Dean and Chapter of 
Winchester Cathedral with regard to the new development plan for the City; his help, too, was sought by New College, Oxford, and Eton College.

Honours, entirely unsought, fell thick upon him. He was awarded the Royal Gold Medal of the R.I.B.A. in 1933, the Gold Medal for Archaeology of this Society in 1938, and received the Order of St. Olaf of Norway. He was appointed to the honorary office of Antiquary to the Royal Academy of Arts.

The number of bodies on whose directing committees he sat would make a long list. He served on the Standing Commission of Museums and Galleries, was a Trustee of the British Museum and the London Museum, a member of the Royal Commission on Historical Monuments, first Chairman of the Management Committee of the Institute of Archaeology, and Treasurer of the National Buildings Record. He was Rhind Lecturer in Archaeology at Edinburgh. He also presided over the International Congress of Prehistoric and Protohistoric Sciences held in London in 1932.

During the First World War he inherited from his father Chiselhampton House in south Oxfordshire, where his forebears had been seated since the middle of the eighteenth century. The founder of the family fortunes was Lord Mayor of London in the reign of George II. The chapel with its beautiful plaster-work has recently been the subject of an appeal for preservation, to which this Society was glad to contribute from the Morris Fund. It was at Chiselhampton that Peers was able to develop his love of horticulture which he applied so successfully to the care of ancient monuments.

He wore his learning very lightly. His charming manners and ready smile were accompanied by a shrewd critical sense and much strength of purpose. As I mentioned in my Anniversary Address of I 950 , no one could put his finger so unerringly on the weak spot in any paper read before him.

He was taken ill on a visit to Ripon in the company of a number of his friends in this Society. He bore a long illness of seven years with the greatest fortitude. During this time his interest in the welfare of the Society never flagged. He wrote from his nursing-home to urge that the opportunity of examining the remains of the Bishop of Winchester's Palace at Southwark, made possible by the war, should be seized. When the writer of this memoir last visited him he had the latest number of the Society's Fournal in his hands. His funeral service was conducted by the Dean in Westminster Abbey, and his remains are laid in the Islip Chapel.

J. G. M. 